\title{
The Case for Citizen Duty
}

\author{
Joseph Mazor
}

\begin{abstract}
This article defends a novel type of institutionalized mass deliberation: Citizen Duty. Citizen Duty would legally require every citizen to engage in one day of diverse, moderated political deliberation prior to major elections. This deliberation would realize a variety of benefits, including wiser electoral decisions and a more respectful electoral process, while avoiding the dangers of citizen deliberation. A comparison with jury duty and with nondeliberative alternatives suggests that Citizen Duty's substantial economic and liberty costs are justified. Finally, an examination of citizen attitudes towards politics and deliberation suggests that Citizen Duty is not as quixotic as it first appears.
\end{abstract}

Keywords: deliberation, democracy, deliberative democracy, elections, Deliberation Day, voter education

A widely-accepted idea in contemporary democratic theory is that collectively-binding decisions are generally better-more legitimate, more respectful, more likely to produce good outcomes - if they are made after the right kind of deliberation. ${ }^{1}$ Yet citizens' electoral choices, as collectively-binding and important as any other political decision, are often made with insufficient deliberation, especially across political lines. Several scholars, including Diana Mutz in Hearing the Other Side $e^{2}$ and Bruce Ackerman and James Fishkin in Deliberation Day, ${ }^{3}$ have called for greater mass electoral deliberation (MED)_-deliberation by a large proportion of citizens regarding the issues at stake in elections. Yet this call has not been widely embraced by democratic theorists.

\footnotetext{
I wish to thank Dennis Thompson, Nancy Rosenblum, Nic Tideman, Peter Dennis, Daniel Chertoff, Minh Ly, and the members of the LSE-Princeton Workshop on Democracy for helpful comments on previous drafts of this article. Thanks also to Alice Siu for help finding data about Deliberative Polls, to Richard Greene for proofreading earlier drafts, and to two anonymous reviewers for their helpful suggestions.

${ }^{1}$ Amy Gutmann and Dennis Thompson, Why Deliberative Democracy? (Princeton, NJ: Princeton University Press, 2004).

${ }^{2}$ Diana Mutz, Hearing the Other Side (New York: Cambridge University Press, 2006).

${ }^{3}$ Bruce Ackerman and James Fishkin, Deliberation Day (New Haven, CT: Yale University Press, 2004).
} 
Proposals for greater MED face four key objections:

1) There is no form of MED that can realize the benefits of citizen deliberation while avoiding its dangers.

2) The costs of greater MED are prohibitively high.

3) There are alternative democratic reforms that can realize benefits similar to MED's at lower costs.

4) Calls for greater MED, especially institutionalized forms of MED, are politically quixotic.

In this article, I shall respond to these objections by proposing a novel form of MED: Citizen Duty. Citizen Duty asks each citizen to participate in one day of carefully-structured deliberation with a small, diverse group of fellow citizens prior to major national elections (with different citizens deliberating on different days). Citizen Duty deliberations would take place outside of participants' local communities, would employ public school teachers as moderators, and would rely on attendance incentives similar to those utilized by jury duty. I shall argue that these features would enable Citizen Duty to realize the benefits of MED while avoiding its dangers.

Admittedly, these features also make Citizen Duty particularly vulnerable to objections regarding costs and political feasibility. However, appealing to a comparison with jury duty, I will argue that Citizen Duty's benefits outweigh its costs and that its use of legal coercion is justified. I will also argue that several alternatives cannot deliver Citizen Duty's distinctive benefits. Finally, I will argue that this type of institutionalized MED is not as politically quixotic as it first appears. Citizen Duty therefore merits careful consideration as a serious proposal for democratic reform. 


\section{Mass Electoral Deliberation Defined}

"Deliberation" in everyday usage means careful thought or discussion about some decision. However, in this article, I will use "deliberation" as shorthand for "minimally desirable interpersonal deliberation." I will assume that deliberation entails at least minimal levels of viewpoint diversity, public-spiritedness, equal respect, and equality of participation. ${ }^{4}$

Mass deliberation is deliberation by a large proportion of a polity's citizenry. In a polity larger than a small village, mass deliberation clearly cannot occur in a single forum. It will instead have to take place in large number of smaller deliberative forums.

Mass electoral deliberation is mass deliberation about the issues at stake in some upcoming election. Of course, MED already occurs informally to some extent in any election. I am interested here in whether MED should be actively encouraged, and, if so, what type and how.

The answers to these questions depend to a considerable extent on electoral context. Throughout this article, I will focus on American presidential elections. However, many of the arguments advanced here could be utilized, with some adjustments, to justify greater citizen deliberation (at least of a certain sort) prior to other elections and even major referenda.

\section{The Benefits of Mass Electoral Deliberation: A Review}

The case for greater mass electoral deliberation rests in large part on MED's sizeable benefits. These benefits have been extensively analyzed by other scholars, and I shall not attempt

\footnotetext{
${ }^{4}$ See Dennis Thompson, "Deliberative Democratic Theory and Empirical Political Science," Annual Review of Political Science, no. 11 (2008): 504-505.
} 
to add to these analyses here. My aim instead will be to offer a brief synthesis of MED's key benefits.

In doing so, I will set aside (for the moment) questions regarding how these benefits can be realized. Yet my discussion will not be wholly divorced from real-world considerations. I recognize that asking citizens to devote a great deal of additional time to deliberation is a normative and practical non-starter. ${ }^{5}$ I will therefore limit my description of MED's benefits to those that can be plausibly realized by one additional day of citizen deliberation per election.

\subsection{A More Informed Electorate}

A key benefit of greater MED is the improvement in political outcomes that can be realized by combatting citizens' political ignorance. This ignorance is one of the most welldocumented facts of American political life. For example, when Americans were asked to associate policy positions with either Al Gore or George W. Bush shortly before the 2000 election, a majority of respondents were only able to associate one policy position correctly with each candidate (and this is likely due to correct guessing). ${ }^{6}$

As Ackerman and Fishkin argue, combatting this political ignorance would lead to better political outcomes in two key ways. First, voters who are more informed are more likely to make wise electoral decisions. ${ }^{7}$ Second, elected representatives who can anticipate being held accountable by more informed voters may well pursue better policies-policies that reflect an informed public opinion rather than the public's misconceptions. ${ }^{8}$

\footnotetext{
${ }^{5}$ As Gutmann and Thompson argue, "For most people, the freedom not to spend a major part of one's life deliberating about politics is part of what it means to lead the life of a free citizen." Why Deliberative Democracy?, 30 .

${ }^{6}$ Ackerman and Fishkin, Deliberation Day, 6.

${ }^{7}$ Ibid., 59-61.

${ }^{8}$ Ibid., 76-77.
} 
Admittedly, citizens cannot be reasonably expected to become even moderately informed about the many complex issues at stake in a presidential election through one additional day of deliberation. ${ }^{9}$ Yet some increase in political knowledge is plausible. If MED focused on a single policy issue, then even several hours of deliberation could plausibly substantially increase citizens' understanding of it. ${ }^{10}$ Alternatively, if MED focused on the electoral choice more generally, even a fairly short period of deliberation could plausibly educate citizens at least about what the most important issues are and where the different candidates stand on them. ${ }^{11}$ Given citizens' abysmally low levels of political knowledge, even such relatively modest improvements could plausibly lead to better political outcomes in the ways described above. ${ }^{12}$

\subsection{Increased Recognition of Reasonable Political Disagreement}

MED can also improve political outcomes by increasing citizens' appreciation for the political disagreement that exists among fellow citizens. As John Hibbing and Elizabeth TheissMorse argue in Stealth Democracy, citizens greatly underestimate the extent of disagreement regarding which political issues are most important. ${ }^{13}$ And they often see policy dilemmas as problems of efficiently implementing commonsense, widely-agreed-upon solutions rather than as the sites of complex empirical and normative controversy that they generally are. ${ }^{14}$

\footnotetext{
${ }^{9}$ For a version of this criticism, see Andrew Sabl, "Deliberation in Its Place," Election Law Journal 4, no. 2 (2005): fn. 9.

${ }^{10}$ Ackerman and Fishkin, Deliberation Day, 72.

11 James Fishkin, When the People Speak: Deliberative Democracy and Public Consultation (Oxford: Oxford University Press, 2009), 138.

${ }^{12}$ I will defend this claim in greater detail in Section 3.3.

${ }^{13}$ When asked how much agreement there was on the most important problem facing the nation, 39\% of respondents said that "most Americans" agree and another 41\% said that "some Americans" (rather than "very few" Americans) agree. However, in reality there is very little agreement. The most popular answer to the question of the most important problem facing the United States (crime) was given by only $6.5 \%$ of respondents. See John Hibbing and Elizabeth Theiss-Morse, Stealth Democracy (Cambridge: Cambridge University Press, 2002), $132-133$.

${ }^{14}$ Ibid., 133.
} 
Combatting citizens' false belief in political consensus would have several benefits. First, it would reduce citizens' unwarranted distrust of representative institutions. As Hibbing and Theiss-Morse argue, citizens' belief in political consensus leads many to see representative institutions, not as arenas for resolving legitimate political disagreements, but rather as sites of dysfunctional bickering at best and corruption by special interests at worst. ${ }^{15}$ Increasing citizens' appreciation for representative institutions could in turn reduce the unfair electoral disadvantage facing "establishment" politicians ${ }^{16}$ and improve compliance with the laws passed by these institutions. $^{17}$

Increasing citizens' appreciation of political disagreement could also foster greater respect for policy expertise. Troublingly, many citizens currently believe that individuals with little policy experience can in fact do a better job governing than experienced legislators. ${ }^{18}$ As Hibbing and Theiss-Morse argue, this attitude is at least in part the result of citizens' failure to appreciate the complex empirical and normative controversies that underlie many policy dilemmas. ${ }^{19}$

Finally, increasing citizens' appreciation for political disagreement could foster greater deliberation and compromise among elected representatives. As many political theorists have argued, these activities are often crucial to good political outcomes. ${ }^{20}$ Yet elected representatives are less likely to engage in these activities when so many voters view them unfavorably. In one

\footnotetext{
${ }^{15}$ Ibid., 133-137

${ }^{16}$ Accusing opponents of being a "Washington insider" is a standard tactic. See, for example, Margery Elfin and Carolyn Kawecki, "A Tale of Two Incumbencies," PS: Political Science \& Politics 26, no. 03 (1993).

${ }^{17}$ For example, many scholars have argued that tax compliance is related to political trust. See Georgia Kaplanoglou and Vassilis T Rapanos, "Why Do People Evade Taxes? New Experimental Evidence from Greece," Journal of Behavioral and Experimental Economics 56 (2015).

${ }^{18}$ Hibbing and Theiss-Morse, Stealth Democracy., 137-143

${ }^{19}$ Ibid.

${ }^{20}$ On the importance of deliberation, see Gutmann and Thompson, Why Deliberative Democracy? On the importance of compromise, see "The Mindsets of Political Compromise," Perspectives on Politics 8, no. 04 (2010).
} 
survey, $86 \%$ of Americans agreed that elected officials should "stop talking and take action." And $60 \%$ agreed that compromise was "the equivalent of selling out on principles rather than a needed concession to legitimate opposing interests for the sake of some kind of solution." ${ }^{21}$ As Hibbing and Theiss-Morse argue, these negative attitudes towards deliberation and compromise stem in large part from citizens' failure to appreciate the extent of political disagreement that exists among their fellow citizens. ${ }^{22}$

It is not difficult to see how even one additional day of MED could improve citizens' recognition of political disagreement. MED would expose citizens to fellow citizens with different views about which policy issues are important and how these issues should be resolved. It could thus plausibly realize, at least to some extent, the considerable benefits associated with combatting citizens' false belief in political consensus.

\subsection{Greater Civic Virtue}

Another benefit of MED is its capacity to increase civic virtue. As Fishkin argues, participating in even one day of deliberation can encourage citizens to consider the public good rather than their narrow self-interest. ${ }^{23}$ Deliberation can also increase citizens' tolerance by exposing them to fellow citizens with different political views, from different religious or ethnic groups, and from different walks of life. ${ }^{24}$ Finally, the greater political knowledge and deliberative skills fostered by deliberation can increase citizens' civic engagement. ${ }^{25}$

\footnotetext{
${ }^{21}$ Hibbing and Theiss-Morse, Stealth Democracy, 136.

${ }^{22}$ Ibid., 134-137.

${ }^{23}$ Fishkin, When the People Speak, 109.

${ }^{24}$ Ackerman and Fishkin, Deliberation Day, 54.

${ }^{25}$ Fishkin, When the People Speak, 143.
} 
Greater civic virtue has three key benefits. First, more public-spirited and tolerant citizens may well support more public-spirited and tolerant candidates and policies. Second, an increase in the tolerance and public-spiritedness of citizens would improve social cohesion and cooperation. Third, greater citizen political engagement would foster a more vibrant democracy.

\subsection{A More Legitimate and Respectful Electoral Process}

The final set of MED benefits are non-instrumental - that is, they do not relate to better political or social outcomes. These are MED's capacity to improve the legitimacy and respectfulness of elections. Note that these normative values are different from citizens' perceptions of electoral legitimacy and respectfulness. Though these perceptions also have important political and social benefits, ${ }^{26}$ I will focus here on the values themselves. ${ }^{27}$

MED can foster electoral respectfulness and legitimacy in four key ways. First, when citizens deliberate prior to voting, they express respect for each other as autonomous agents who should understand and have some say in the important collectively-binding choices that shape their lives. ${ }^{28}$ Second, by deliberating prior to voting, citizens express respect for others by taking care with a decision that has enormous, coercively-binding consequences for others' lives. ${ }^{29}$ Third, receiving justifications (at least of a certain sort) from the relevant decision-makers can make collectively-binding decisions more legitimate. ${ }^{30}$ Finally, due to its capacity to increase

\footnotetext{
${ }^{26}$ For example, a greater perception of political legitimacy can foster citizens' willingness to comply with policies they oppose. See James Gibson, Gregory Caldeira, and Lester Spence, "Why Do People Accept Public Policies They Oppose? Testing Legitimacy Theory with a Survey-Based Experiment," Political Research Quarterly 58, no. 2 (2005).

${ }^{27}$ If mass electoral deliberation fosters electoral respectfulness and legitimacy, it is also likely to foster citizens' perceptions of these values (and the associated political benefits).

${ }^{28}$ See, for example, Charles Larmore, "The Moral Basis of Political Liberalism," Journal of Philosophy 96, no. 12 (1999).

${ }^{29}$ Ackerman and Fishkin, Deliberation Day, 175-176.

${ }^{30}$ Amy Gutmann and Dennis Thompson, Democracy and Disagreement (Cambridge, MA: Belknap Press, 1996), $41-42$.
} 
political knowledge, MED can increase the likelihood of elections reflecting an informed democratic will, thus increasing elections' democratic legitimacy. ${ }^{31}$

Some may doubt that one day of deliberation would make much of a difference.

However, given that many citizens currently cast their votes-decisions with enormous consequences for fellow citizens' lives_-based on little more than top-of-the-head impressions, news snippets, and cues, ${ }^{32}$ even a modest increase in voters' levels of care and knowledge could generate substantial increases in electoral respectfulness and legitimacy. These non-instrumental benefits, along with the instrumental benefits discussed above, constitute a strong pro tanto case in favor of greater MED.

\section{Meeting the Challenges of Citizen Deliberation}

Many opponents of greater mass electoral deliberation do not deny that it has considerable benefits in theory. However, they doubt whether MED would realize these lofty benefits in practice. Indeed, they argue that greater MED would actually be harmful. ${ }^{33} \mathrm{My}$ aim in this section is to rehearse the problems with greater citizen deliberation and to argue that there is a form of MED that can avoid them.

\subsection{The Challenges of Citizen Deliberation: A Brief Review}

Opponents of greater mass electoral deliberation have several well-grounded concerns.

First, they question citizens' willingness to participate in deliberation. ${ }^{34}$ Even assuming that

\footnotetext{
${ }^{31}$ Ackerman and Fishkin, Deliberation Day, 192-193.

${ }^{32}$ For a discussion, see Samuel Popkin, The Reasoning Voter (Chicago: University of Chicago Press, 1991).

${ }^{33}$ See, for example, Hibbing and Theiss-Morse, Stealth Democracy, 190-191.

${ }^{34}$ For a discussion of the skeptics' position, see Michael Neblo et al., "Who Wants to Deliberate—and Why?," American Political Science Review 104, no. 03 (2010): 567.
} 
MED would be beneficial for society as a whole, the costs of participation (e.g., the lost time) must be borne by individuals. Inducing citizens to deliberate therefore requires overcoming the same type collective action problem that underlies citizens' failure to become more politically informed. ${ }^{35}$

Indeed, inducing citizens to deliberate is more challenging than inducing them to engage in other types of political learning. Conflict-averse citizens find the prospect of witnessing political arguments to be off-putting. ${ }^{36}$ And other citizens may be less than eager to sit through the often stilted and meandering deliberation of ordinary people. ${ }^{37}$ Finally, though deliberation provides an opportunity for participation, many citizens may be uncomfortable speaking in front of others or may be worried about the social consequences of sharing unpopular, uninformed, or inarticulate views. ${ }^{38}$ If deliberation only attracts a small number of participants who are already passionately committed to certain views, it is very unlikely to realize the benefits described above.

Even if a large proportion of citizens participate, there are several other reasons for doubting the capacity of MED to realize the benefits described above. First, given citizens' ignorance and propensity to focus on the salacious, MED may misinform more than it informs. ${ }^{39}$ Second, if the deliberative forums that constitute MED lack diversity, MED may confirm citizens' false belief in political consensus. Third, insufficient diversity could serve to increase the participants' commitment to their group interest at the expense of the public good. ${ }^{40}$ Fourth, MED can bring hidden conflicts to light, thus increasing rather than ameliorating social

\footnotetext{
${ }^{35}$ For one discussion of this problem, see Ackerman and Fishkin, Deliberation Day, 8.

${ }^{36}$ Hibbing and Theiss-Morse, Stealth Democracy, 135.

${ }^{37}$ For an example of such deliberation, see John Gastil, By Popular Demand (Berkeley, CA: University of California Press, 2000), 133-134.

${ }^{38}$ Jane Mansbridge, Beyond Adversary Democracy (New York: Basic Books, 1980), 62.

${ }^{39}$ Hibbing and Theiss-Morse, Stealth Democracy, 192-194.

${ }^{40}$ Ibid., 206
} 
conflict. ${ }^{41}$ Finally, if deliberation lacks civility or if the arguments made are ignorant, selfish, or prejudiced, then deliberation may, if anything, reduce electoral legitimacy and respectfulness. ${ }^{42}$

Citizen deliberation has three additional well-known dangers. First, if deliberation lacks sufficient viewpoint diversity, it can lead participants to polarize, adopting views that are in the majority in their particular deliberative forum due an imbalanced pool of arguments. ${ }^{43}$ Such polarization can further undermine tolerance and social cooperation across political lines. Second, increased MED can expose citizens to unfairly harsh punishments for expressing certain political views, especially those that are locally unpopular. ${ }^{44}$ Finally, MED could exacerbate political inequalities by favoring the views of the more privileged. ${ }^{45}$ Thus, while MED may be attractive in theory, there are good reasons for doubting its capacity to realize substantial net benefits in practice.

\subsection{The Problems with Relying on Norm Change}

Proponents of greater mass electoral deliberation are generally well-aware of MED's dangers. Yet they believe that measures can be taken to avoid them. One camp of MED proponents propose addressing the shortcomings of citizen deliberation by changing the social norms governing everyday political discussions. Diana Mutz, for example, calls for media campaigns, civics education reform, and changes in democratic institutions (e.g., the atmosphere

\footnotetext{
${ }^{41}$ Ibid., 201-203

42 Ibid., 196-201.

${ }^{43}$ For a discussion, see Cass Sunstein, Why Societies Need Dissent (Cambridge, MA: Harvard University Press, 2003).

${ }^{44}$ For a discussion of the extent of political discrimination, see Shanto Iyengar and Sean Westwood, "Fear and Loathing across Party Lines: New Evidence on Group Polarization," American Journal of Political Science 59, no. 3 (2015). Protecting citizens from such punishments is a key reason for the secret ballot, and some have suggested that the possibility of such punishments also justify rejecting calls for greater mass electoral deliberation. See, for example, Dennis Thompson, "The Role of Theorists and Citizens in Just Elections: A Response to Professors Cain, Garrett, and Sabl," Election Law Journal 4, no. 2 (2005): 160.

${ }^{45}$ Lynn Sanders, "Against Deliberation," Political Theory 25, no. 3 (1997).
} 
of national debates) aimed at increasing the value that citizens place on respectful engagement with those holding opposing political views. ${ }^{46}$ Mutz hopes that these norm changes will make citizens' everyday political discussions, especially those across political lines, more frequent and constructive. $^{47}$

However, there are several problems with relying on social norm change to address the challenges of citizen deliberation. First, as many scholars have recognized, altering social norms is no easy task. ${ }^{48}$ And the norms of political intolerance that Mutz hopes to alter are wellentrenched and becoming stronger, at least in the United States. ${ }^{49}$ Moreover, even if these norms can be transformed (e.g., through civics education), this will require a great deal of time. ${ }^{50}$ Yet the problems that MED aims to address are pressing.

In addition, several social norms besides those associated with political intolerance would have to change to avoid the dangers described above. For example, norms that make political ignorance socially acceptable and norms connecting social status to the deference paid to views will also need to be addressed to combat deliberation's propensity to spread misinformation and to exacerbate political inequality. Attempting to substantially alter all of the relevant norms is an enormously challenging undertaking.

Finally, many of the obstacles to beneficial MED cannot be easily addressed by norm change. For example, local American viewpoint homogeneity would continue to hamper discussions across political lines, even if social norms were more conducive to such

\footnotetext{
${ }^{46}$ Mutz, Hearing the Other Side, 141-151.

${ }^{47}$ Ibid., Chapter 3.

${ }^{48}$ Cristina Bicchieri, Norms in the Wild: How to Diagnose, Measure, and Change Social Norms (Oxford: Oxford University Press, 2016).

${ }^{49}$ See Iyengar and Westwood, "Fear and Loathing across Party Lines: New Evidence on Group Polarization."

${ }^{50}$ As I point out in Section 5.3, any proposal that relies on civics education reform will require around a quarter of a century before it will influence even the majority of voters.
} 
discussions. ${ }^{51}$ Norm change would also not address the economic inequalities that enable some citizens to spend more time than others learning about politics. Thus, while altering social norms may well address some of the challenges facing citizen deliberation (and may thus be worth pursuing), norm change alone is highly unlikely to induce large percentages of citizens to participate in civil, constructive deliberation across political lines given existing levels of political ignorance, apathy, local viewpoint homogeneity, conflict aversion, social inequality, and political intolerance in the United States.

\subsection{Deliberative Polls and the Promise of Institutionalized Deliberation}

However, there is an alternative approach. Rather than attempting to fundamentally transform everyday political discussions, society can institute artificial deliberative forums carefully designed to overcome the challenges of MED. That is, society can implement institutionalized mass electoral deliberation.

I will argue in the rest of this section that a certain type of institutionalized MED that I call Citizen Duty can realize the benefits of citizen deliberation while avoiding its dangers. I begin here by defending a relatively modest claim: Society would be able to realize the benefits of MED while avoiding its dangers if it could implement (on a national scale) deliberative forums with consequences akin to those of Deliberative Polls (i.e., if it could "scale up" Deliberative Polls).

A Deliberative Poll (DP) is a deliberative forum that brings together small groups of citizens for a relatively short period (e.g., a weekend) of moderated deliberation, with the aim of

\footnotetext{
${ }^{51}$ For a discussion of local political homogeneity, see Bill Bishop, The Big Sort: Why the Clustering of Like-Minded America Is Tearing Us Apart (New York, NY: First Mariner Books, 2008), Chapter 2.
} 
revealing to policymakers and to the general public what informed public opinion would be on the topics discussed. ${ }^{52}$ DP participants are chosen to ensure representativeness, enticed with a generous honorarium, and sent balanced briefing materials prior to the deliberation. At the deliberation itself, participants are tasked, not with resolving political controversies, but rather with determining via small-group discussion which questions should be posed to a diverse panel of experts. Participants then attend a plenary session in which their questions are posed to these experts. This small group/plenary session process repeats several times throughout the DP. At the end of the DP, participants are generally given an opportunity to share their views with fellow deliberators.

DPs have been extensively studied, and the available evidence strongly suggests that scaled-up DPs would realize the benefits of MED while avoiding its dangers. First, DPs have been shown to engender substantial levels of participant learning. ${ }^{53}$ For example, participating in a DP about the economic issues at stake in the 1997 British general election increased participants' percentage of correctly answered questions regarding these issues by 14 percentage points (from $47 \%$ to $61 \%$ ). And participants' ability to identity parties with their policy positions increased by 7 percentage points (from $41 \%$ to $48 \%$ ). DP also routinely engender sizeable changes in policy attitudes and voting intentions. And these changes have been shown to be driven by better information. ${ }^{54}$ Assuming that more informed voters tend to make better choices, and assuming that political outcomes are responsive to voter preferences, scaling up DPs is likely to significantly increase the probability of good political outcomes.

\footnotetext{
${ }^{52}$ For a more thorough description of Deliberative Polls, see Fishkin, When the People Speak, 25-26.

53 Ibid., 134.

${ }^{54}$ Ackerman and Fishkin, Deliberation Day, 52-54.
} 
Scaling up DPs is also likely to foster civic virtue as well as electoral respectfulness and legitimacy. DPs have been shown to increase participants' tolerance,${ }^{55}$ public-spiritedness, ${ }^{56}$ and various forms of political engagement. ${ }^{57}$ Participants generally rate DP discussions as highly respectful. ${ }^{58}$ And given DPs' capacity to improve voter knowledge, scaling up DPs would ameliorate the problems of electoral legitimacy and respectfulness associated voter ignorance. Finally, the diversity of DP participants encourages deliberators to give widely accessible reasons for their political positions, ${ }^{59}$ a factor that many democratic theorists argue is key to these justifications' legitimizing force. ${ }^{60}$

A reform that scaled up DPs would also avoid the well-known dangers of citizen deliberation. Polarization does not predictably occur at DPs. ${ }^{61}$ The opinion of participants does not predictably move in the direction of the more privileged. ${ }^{62}$ And since DP deliberations occur outside of participants' local communities, participants face little danger of substantial social sanctions for expressing unpopular views.

The potential of scaled-up DPs to foster citizens' appreciation for political disagreement is admittedly less clear. This DP effect has not been extensively studied, and the scant available evidence is, if anything, discouraging. In one DP about proposed political reforms in California, participants were asked whether those endorsing positions very different from their own had

\footnotetext{
55 Ibid., 54.

${ }^{56}$ Fishkin, When the People Speak, 139-142.

${ }^{57}$ Ibid., 142-143.

${ }^{58}$ For one example, see James Fishkin et al., "What's Next California Report: Summary Results," (Stanford University: Center for Deliberative Democracy, 2011), 34.

${ }^{59}$ Ackerman and Fishkin, Deliberation Day, 212.

${ }^{60}$ Gutmann and Thompson, Democracy and Disagreement, Chapter 2.

${ }^{61}$ Ackerman and Fishkin, Deliberation Day, 131-133.

${ }^{62}$ Ibid., 128-131.
} 
"good reasons" for their views. Participants' answer to this question in fact became slightly less positive after deliberation. ${ }^{63}$

However, this does not provide strong grounds for doubting the capacity of scaled-up DPs to increase citizens' appreciation of political disagreement. First, this result might be an artifact of the particular design of the California DP. Only a tiny fraction of the weekend-long DP's time (45 minutes) was devoted to providing participants with an opportunity to share their post-deliberative views with fellow participants. And this limited time had to compete with a variety of administrative tasks (e.g., filling out final questionnaires and reimbursement forms). ${ }^{64}$ Allowing additional time for the sharing of post-deliberative views could well improve citizens' appreciation of outstanding political disagreements.

Second, in the California DP, participants were not making any collectively-binding decision post-deliberation. Participants' motivation to use their closing statement to appeal to those who do not share their views (thus highlighting the remaining political disagreements) was likely lower than it would be in the case of deliberation regarding an upcoming presidential election.

Finally (and most importantly), the survey question above fails to capture the politically relevant attitude. What is important is that citizens recognize their opponents' political justifications as minimally reasonable (rather than "good"). This is sufficient to increase citizens' appreciation for representative institutions, policy expertise, deliberation, and compromise. For example, progressive citizens who learn that conservative citizens have economic-growth-based or liberty-based reasons for lowering taxes on the wealthy may not agree that these are "good"

\footnotetext{
${ }^{63}$ Fishkin et al., "What's Next California Report: Summary Results," 29.

64 "What's Next California: Event Agenda," accessed June 5, 2019, http://action.nextca.org/page//WhatsNextCA_EventAgenda.pdf.
} 
reasons for lower taxes. However, they might nevertheless concede that these justifications are minimally reasonable and thus worthy of representation, worthy of being listened to, and perhaps even worth taking into account to some extent in tax policy.

More research is needed on this issue. However, given the available evidence and the arguments above, there are good reasons for thinking that a reform that scaled up the success of DPs would realize the benefits of mass electoral deliberation while avoiding its dangers.

\subsection{The Problems with Deliberation Day}

The idea of scaling up Deliberative Polls is not new. Indeed, this is precisely the aim of Ackerman and Fishkin's Deliberation Day (DDay) ${ }^{65}$ DDay is a proposed two-day national holiday during which all citizens would be invited to engage in one day of electoral deliberation in their local communities shortly before presidential elections. Like DPs, DDay groups would be constituted by a small number of citizens tasked with choosing questions to pose to a panel of experts (which, in the case of DDay, would be constituted by party representatives). And, like DP participants, DDay participants would be paid a considerable amount (\$150) to attend. ${ }^{66}$ However, there are also substantial differences between DDay and DPs-differences that I will argue undermine DDay's capacity to scale up DPs.

The first is the difference in the participation rates required for success. A $20 \%$ participation rate for a DP (which is not atypical) ${ }^{67}$ does not undermine the DP's aim of revealing what informed public opinion would be (as long as the attendees are representative of the general

\footnotetext{
65 Ackerman and Fishkin, Deliberation Day, 44-45.

${ }^{66}$ For a full description of DDay, see ibid., Chapter 2.

${ }^{67}$ In one DP in the United Kingdom, around 35\% of those invited actually attended. See James Fishkin, The Voice of the People (New Haven, CT: Yale University Press, 1995), 166. However, in a DP in New Haven, CT only around $13 \%$ of those initially interviewed ultimately attended. See Cynthia Farrar et al., "Disaggregating Deliberation's Effects: An Experiment within a Deliberative Poll," British Journal of Political Science 40, no. 2 (2010): 139.
} 
public). On the other hand, a 20\% participation rate would severely curtail DDay's capacity to combat voter ignorance, foster appreciation of political disagreement, increase civic virtue, and improve electoral legitimacy and respectfulness. Indeed, if only a small percentage of citizens deliberate, and if the outcome endorsed by deliberators is different from the outcome endorsed by the non-deliberating majority, DDay could well decrease the democratic legitimacy of the electoral result (since those on the losing side could argue that their preferred outcome represents the true democratic will).

Admittedly, there are reasons for thinking that DDay participation rates will be higher than DPs'. The DDay honorarium is somewhat higher than the typical day-long DP's, the travel burden is less onerous, the sense of civic duty to attend DDay would likely be stronger, and the promise of catching up with friends and neighbors at the local deliberation may serve as substantial inducements to attend. ${ }^{68}$

Yet there are also reasons for thinking that DDay participation rates will be lower than DPs'. DP participants do not have to worry about unwelcome interactions with acquaintances and neighbors, are promised media attention, and often receive individualized assistance from DP organizers in addressing their attendance difficulties. Moreover, while DPs generally take place in high-quality venues (e.g., universities, hotels, conference centers), DDay's attempt to accommodate tens of millions of deliberators over two days requires using deliberation spaces that are far less ideal (e.g., elementary schools with rented chairs or places of worship). ${ }^{69}$

DDay's two-day timeframe also creates special attendance obstacles for certain groups of citizens. Consider, for example, those responsible for childcare. While DP participants have a

\footnotetext{
${ }^{68}$ For an in-depth discussion of the differences between DDay and DPs, see Ackerman and Fishkin, Deliberation Day, 65-73.

${ }^{69}$ Ibid., 135, 258. In addition to disincentivizing attendance, the use of such non-ideal spaces raises concerns about deliberation quality and the separation of church and state.
} 
variety of childcare options, it is unclear who will take care of society's children during a twoday holiday in which schools are closed and a substantial proportion of adults are either deliberating or working. It is also unclear where childcare will take place if schools, community centers, and places of worship are used for deliberation. After all, there are nowhere near enough experienced teenage babysitters to provide home supervision to a substantial fraction of society's children on a particular day. DDay's two-day format raises similar problems for those providing informal eldercare and makes attendance very difficult for those employed in essential services. Thus, DDay participation rates may well be even lower than the fairly low participation rates achieve by DPs. ${ }^{70}$

Some of these participation problems could admittedly be ameliorated by increasing the DDay honorarium. However, the exclusive reliance on high payments to induce attendance is problematic. First, high attendance payments may "crowd out" duty-based attendance motivations. ${ }^{71}$ Second, unless the payment was very high indeed, it would be unlikely to motivate high-income individuals with attendance difficulties to attend. Finally, while a sufficiently high payment would no doubt achieve a high participation rate, it would very substantially increase DDay's economic costs as well as the coercion imposed on taxpayers. ${ }^{72}$ Thus, DDay's participation challenges cannot be attractively solved by a higher honorarium.

Another problematic difference between DDay and DPs is the absence of moderators. Ackerman and Fishkin reject the use of moderators primarily due to concerns about the capture

\footnotetext{
${ }^{70}$ Note that these participation difficulties will likely fall more heavily on some groups than others (e.g., women due to social expectations regarding childcare), thus undermining the diversity of DDay.

${ }^{71}$ For a discussion of this general phenomenon, see Bruno Frey and Reto Jegen, "Motivation Crowding Theory," Journal of Economic Surveys 15, no. 5 (2001).

${ }^{72}$ Below, I (very roughly) estimate the economic costs of MED assuming an honorarium of $\$ 150$. A doubling of this honorarium would add around $\$ 6.5$ billion dollars to these estimated costs due to the efficiency costs associated with the higher necessary taxation.
} 
of the moderator core by political parties. ${ }^{73}$ Yet moderators play several important roles in DPs. They help keep the deliberation civil, clarify and synthesize participants' points, keep participants on task, and actively encourage equality of participation. ${ }^{74}$

Ackerman and Fishkin propose replacing moderators with a citizen foreman charged with enforcing 90 -second speaking turns. ${ }^{75}$ However, this is a recipe for stilted deliberation. And since the rhetorical skill needed to make a coherent point in 90 seconds is unequally distributed, and since more reticent participants (who are often more socially disadvantaged) may need active participation encouragement, simply guaranteeing formal equality of speaking opportunity is unlikely to achieve DP-levels of equality of participation and influence.

Yet another problematic difference between DDay deliberations and DPs is DDay's lack of focus. Ackerman and Fishkin allow each presidential candidate to raise two issues for DDay deliberation. They also explicitly allow opportunities for citizens to raise a variety of other issues for discussion. ${ }^{76}$ The resulting number of topics is far greater than those discussed in DPs relative to the time allotted. Yet without focused discussion of at least several hours on a single policy issue, it is unclear whether anything like the typical DP levels of learning will occur.

However, the most problematic difference between DDay and DPs is the local character of DDay deliberations. Local deliberations would considerably undermine viewpoint diversity. Note that, in some communities, rates of support for particular presidential candidates are above $80 \% .{ }^{77}$ And participants who are in the political minority locally may decide not to attend or to remain silent due to the fear of social sanctions. Yet without viewpoint diversity in DDay's

\footnotetext{
${ }^{73}$ Ackerman and Fishkin, Deliberation Day, 65-66.

${ }^{74}$ Fishkin, When the People Speak, 132.

75 Ackerman and Fishkin, Deliberation Day, 27.

${ }^{76}$ Ibid., 25-27.

77 Thomas Frohlich and Alexander Kent, "The Most Democratic County in Every State," Huffington Post, accessed June 5, 2019, http://247wallst.com/special-report/2016/10/08/the-most-democratic-county-in-everystate/2/?utm_source=huffingtonpost.com\&utm_medium=referral\&utm_campaign=pubexchange_article.
} 
constitutive deliberative forums, many of the benefits of scaled up DPs are unlikely to be realized. And the problem of polarization (which DPs are able to avoid) is likely to arise.

Indeed, there is evidence to support this final concern. In "What Happened on Deliberation Day?," Hastie, Schkade, and Sunstein conducted an experiment in which citizens deliberated in Boulder, Colorado (a progressive community) and in Silver Springs, Colorado (a conservative community) about global warming, affirmative action, and same-sex marriage. The result was substantial viewpoint polarization, with deliberators' views in Boulder becoming more progressive and deliberators' views in Silver Springs becoming more conservative. ${ }^{78}$ This evidence further undermines Ackerman and Fishkin's claim that DDay would scale up the success of DPs.

\subsection{The Promise of Citizen Duty}

However, the problems with DDay need not lead us to abandon the idea of scaling up Deliberative Polls. I will argue here that there is an alternative form of institutionalized MED that can avoid DDay's shortcomings: Citizen Duty.

The Citizen Duty process would begin approximately one year prior to presidential elections with the convening of a Citizen Assembly — a randomly chosen group of 100 citizens who would be invited to Washington DC for several weekends (with selection methods and participation incentives similar to those used in DPs). This Assembly's most important task would be to choose one policy issue to be discussed during the morning of Citizen Duty deliberations. The Assembly would consider polls of which issues citizens view as most

\footnotetext{
${ }^{78}$ Reid Hastie, David Schkade, and Cass Sunstein, "What Happened on Deliberation Day?," California Law Review 95 (2007).
} 
important, listen to the parties' views, and also hear from experts regarding the issue characteristics most conducive to productive deliberation. After choosing the issue, the Assembly would then be tasked with approving the work of a bipartisan commission charged with constructing balanced briefing materials on this issue (similar to the materials used for DPs).

Shortly after the Citizen Assembly makes its issue selection, all citizens would be invited to submit preferences for a deliberation date from among the weekdays of their state's public school summer holiday. These preferences, along with demographic data and party registration information, would then be used to algorithmically assign citizens to politically diverse twelveperson deliberating groups at a particular date and location. To foster viewpoint diversity, the assigned locations will be well outside of the citizens' local community. However, to limit the demands on participants, the location will be within the distance limit from the citizen's home used for federal jury duty (e.g., 80 miles in Northern California) ${ }^{79}$ School busses (many of which are unused over the summer) would be utilized to facilitate transportation.

In the early spring, citizens would receive their assigned Citizen Duty date and location. Attendance would be legally required (with penalties for non-attendance similar to those used for jury duty) ${ }^{80}$ However, the compensation for attendance would be more generous than jury duty compensation. All employers above a certain size would be legally required to pay their employees' salaries for the day. And any participant who does not receive at least $\$ 150$ of compensation from an employer would be entitled to refundable tax credit sufficient to ensure

\footnotetext{
79 "Jury Frequently Asked Questions: Northern District of California," accessed June 5, 2019, http://www.cand.uscourts.gov/juryfaq., Question 5

${ }^{80}$ For a description of the penalties for avoiding jury duty, see ibid., Question 17.
} 
that she receives at least $\$ 150$ (or whatever the median wage is at the time) in participation compensation.

Citizen Duty deliberations would begin with a pre-recorded candidate debate about the policy issue chosen by the Citizen Assembly (with questions chosen by the Assembly). As in the case of DDay, participants would then engage in moderated small-group deliberations regarding what further questions to pose to local party representatives about this issue. Next, participants would gather for a late-morning plenary session during which the party representatives would answer the small groups' questions. Citizens would then be provided with boxed lunches, which they would be encouraged to eat with their small deliberating group.

The afternoon of Citizen Duty would be devoted to the electoral choice more generally. It would begin with a second pre-recorded candidate debate about this choice (with topics and questions chosen by the Citizen Assembly). This debate would be followed by small-group deliberation on which questions to pose to the party representatives regarding the issues discussed in the afternoon's debate (or any other election-related issue that citizens feel is important). An afternoon plenary session would follow, during which the local party representatives would once again answer the small groups' questions. The day would conclude with an hour in which citizens would have an opportunity to share their post-deliberative views regarding the morning's policy issue and the electoral choice more generally with their fellow deliberators (with no more than five minutes allocated per person).

Citizen Duty's design addresses the shortcomings of Deliberation Day in several ways. First, Citizen Duty's participation incentives make high attendance far more likely. Given the use of legal coercion, a good lower-bound estimate of the Citizen Duty participation rate is the 
approximately $50 \%$ rate of compliance achieved by jury duty in the United States ${ }^{81}$ However, given Citizen Duty's more substantial compensation and the fact that only one day of deliberation is required at a time, participation rates for Citizen Duty may well be substantially higher. A good upper-bound estimate is the rate of compliance with the legal requirement to vote in Australia (which lies above 90\%). ${ }^{82}$

Spreading MED across the summer school holiday solves several additional problems. First, Citizen Duty deliberations can take place exclusively in fairly high-quality venuesunused high school and middle school classrooms and auditoriums. ${ }^{83}$ Second, spreading out MED dramatically reduces the participation obstacles for those responsible for childcare, eldercare, and essential services.

Citizen Duty's summer timeframe also allows for an attractive solution to the problem of moderators. Public school teachers can be hired and trained for this role. ${ }^{84}$ Many teachers seek summer employment, and many already have significant skills in discussion facilitation. Moreover, public school teachers are already trusted (at least by many) to stay politically neutral in their classrooms. Finally (and most importantly), it seems highly unlikely that anyone would become a public school teacher in order to become a Citizen Duty moderator, thus addressing Ackerman and Fishkin's worry about moderators' political capture. ${ }^{85}$

Citizen Duty addresses DDay's problematic lack of focus by devoting the morning of deliberation to the single policy issue (chosen by the Citizen Assembly). This admittedly

\footnotetext{
${ }^{81}$ Michael Singer, Jury Duty: Reclaiming Your Political Power and Taking Responsibility (Santa Barbara, CA: ABC-CLIO, 2012), 33.

${ }^{82}$ Katie Beck, "Australia Election: Why Is Voting Compulsory?," BBC News, accessed June 5, 2019, http://www.bbc.com/news/world-asia-23810381.

${ }^{83}$ Assuming 180 million participants, 40 days of Citizen Duty, and two staggered starting times, space is only needed for 2.25 million deliberators per day.

${ }^{84}$ See, for example, Fishkin, When the People Speak, 107.

${ }^{85}$ The use of teachers as moderators would admittedly make discussions of educational policy problematic. Moreover, public school teachers as a profession display a left-leaning bias. However, this bias is far less
} 
sacrifices some breadth of learning. However, it is unrealistic to expect deep learning on a broad range of policy issues from a single day of deliberation in any case. The morning's focus on a single issue would encourage learning on this issue prior to deliberation and would enable citizens to better recognize this issue's moral and empirical complexity (and, after several Citizen Duty experiences, the moral and empirical complexity of policy issues more generally). The afternoon's deliberation about the electoral choice would still provide citizens with sufficient opportunity to learn something about other major issues (e.g., what they are and where the parties stand on them), would enable citizens to recognize the disagreements among fellow citizens regarding which issues are most important, and would provide an opportunity for citizens to raise issues not discussed during the candidate debates.

Finally, Citizen Duty's non-local character solves two key problems facing DDay. First, it protects citizens from being subjected to social sanctions for expressing locally-unpopular views. Second, it enables Citizen Duty to achieve far greater viewpoint diversity within its constitutive small deliberating groups. Indeed, a cursory examination of county-level presidential election data suggests that a travel requirement in the neighborhood of 80 miles would be sufficient to achieve a great deal of viewpoint diversity, especially since conservatives and progressives in particularly homogeneous areas of the country can be asked to meet at an intermediate location. ${ }^{86}$

In the case of citizens in highly homogenous parts the country, those serving overseas, and those with severe mobility difficulties, Citizen Duty deliberations could be conducted

pronounced than teachers' union activity might suggest. See Hanna Skandera and Richard Sousa, School Figures: The Data Behind the Debate (Stanford, CA: Hoover Press, 2003), 112-113.

${ }^{86}$ For helpful maps, see Mark Newman, "Maps of the 2016 United States Presidential Election Results," accessed June 5, 2019, http://www-personal.umich.edu/ mejn/election/2016/. 
online. ${ }^{87}$ Though online deliberation is not as effective as face-to-face deliberation (and should therefore not be used for Citizen Duty in general), it has been shown to achieve at least some of the benefits of Deliberative Polls. ${ }^{88}$

In sum, Citizen Duty's legally-required attendance, use of moderators, focus of the morning's deliberation on a single issue, and travel requirements make it far more likely than DDay to nationally scale up DPs' success. There are thus good reasons for thinking that Citizen Duty would realize the benefits of citizen deliberation while avoiding its dangers.

\section{Justifying Citizen Duty's Costs}

Admittedly, the measures Citizen Duty employs to address the challenges of mass electoral deliberation make it particularly vulnerable to cost-based objections. The high economic costs of Citizen Duty include the costs of participants' time, administrative and logistical expenses, participant travel, moderators' training and salaries, the expenses of the Citizen Assembly, and the economic costs associated with raising the necessary tax revenue. Although I cannot calculate these costs in detail here, a back of the envelope calculation suggests that they could run as high as $\$ 44$ billion (given a very optimistic assumption of 180 million Citizen Duty participants). ${ }^{89}$ Yet, as Ian Shapiro argues, the benefits of one day of citizen

\footnotetext{
${ }^{87}$ Ackerman and Fishkin, Deliberation Day, 115-119.

${ }^{88}$ Fishkin, When the People Speak, 170-171.

${ }^{89}$ The biggest cost is the deliberators' time, which I very roughly estimate at $\$ 150$ per person. Optimistically assuming that 180 million of the 208 million eligible voters will participate, this comes to $\$ 27$ billion. Assuming 15 million deliberating groups (180/12), two groups per moderator per day and an average of 40 days of available deliberation, around 187,500 moderators will be needed. At a cost of $\$ 8,000$ per moderator, this will come to $\$ 1.5$ billion. Ackerman and Fishkin estimate all of the other costs of an institutionalized national deliberation (food, administration, transportation, custodial, etc.) to be about $\$ 2.3$ billion for 70 million participants. Since the transportation costs and the costs associated with the number of participants will be significantly higher for Citizen Duty, but many of the other costs (e.g., those associated with preparing low-quality spaces for deliberation) will be lower, I estimate that these costs as well as other miscellaneous costs (e.g., conducting the Citizen Assembly) will be about $\$ 6$ billion. Finally, I estimate the deadweight loss from raising the necessary funds at approximately 25 cents on the dollar. This adds approximately $\$ 9$ billion dollars of economic costs, leading to a total of $\$ 44$ billion.
} 
deliberation hardly seem worth billions of dollars. ${ }^{90}$ Moreover, Citizen Duty legally requires attendance. This constitutes a substantial infringement on citizens' liberty - a weighty moral cost that also requires justification.

In this section, I will offer two justifications for Citizen Duty's costs. First, I will offer a consequentialist argument aimed at establishing that Citizen Duty's benefits are greater than its costs. Second, I will suggest that Citizen Duty has a set of features relating to certain rights and duties that are jointly sufficient to justify its use of coercion.

\subsection{A Consequentialist Defense of Citizen Duty's Costs}

At first glance, it is unclear how one could evaluate whether Citizen Duty's benefits are greater than its costs. How should we compare the benefits of greater legitimacy to travel costs or the protection of rights to the cost of coercion? Trying to find a dollar equivalent for these benefits and costs (as is done in traditional cost-benefit analysis) would be highly complex, speculative, and morally controversial. ${ }^{91}$

Fortunately, there is a way to avoid having to find a common metric for these diverse costs and benefits - a comparison with jury duty. Jury duty has benefits and costs very similar to Citizen Duty's. Thus, if jury duty's benefits are greater than its costs (as I will assume), ${ }^{92}$ and if the benefits of Citizen Duty are greater than the benefits of jury duty (as I will argue), then Citizen Duty's benefits are greater than its costs.

\footnotetext{
${ }^{90}$ Ian Shapiro, "The State of Democratic Theory: A Reply to James Fishkin," Critical Review of International Social and Political Philosophy 8, no. 1 (2005).

${ }^{91}$ For a discussion, see Steven Kelman, "Cost-Benefit Analysis: An Ethical Critique," AEI Journal on Government and

Society Regulation, January/February (1981).

${ }^{92}$ Note that jury duty enjoys substantial public support. See Singer, Jury Duty, 32.
} 
This argument first requires determining the span of jury duty whose costs are equivalent to Citizen Duty's. Michael Singer estimates the lower bound of jury duty's yearly costs at 9 million legally-required citizen-days and a little over $\$ 2$ billion. ${ }^{93}$ Thus, given the estimates above, Citizen Duty for one presidential election would have economic and liberty costs on par with 20 years of jury duty. The question, then, is this: Are the expected benefits of Citizen Duty for one presidential election greater than the benefits of 20 years of jury duty? I will argue that they are.

\subsubsection{The Benefits of Jury Duty}

Defenders of jury duty justify its high costs by appealing to several key benefits. These benefits are admittedly controversial, and settling the relevant debates is beyond the scope of this article. However, since my aim is to argue that Citizen Duty's benefits are greater than jury duty's, I will adopt an optimistic view of jury duty's benefits in order to make my argument more robust.

The first benefit of jury duty is the greater protection of rights, primarily via more accurate trial judgments. ${ }^{94}$ There are approximately 150,000 jury trials per year in the United States or 3 million trials over the course of 20 years ${ }^{95}$ Scholars have estimated that there is a difference between the decision the jury reaches and the decision the judge would have reached in an estimated $1 / 5^{\text {th }}$ of trials. ${ }^{96}$ Thus, over the course of 20 years, roughly 600,000 trial outcomes are affected by the use of juries.

\footnotetext{
${ }^{93}$ Ibid., 16, 23.

${ }^{94}$ For a skeptical discussion, see ibid., Chapter 4.

${ }^{95}$ Ibid., 22.

${ }^{96}$ Ibid., 44.
} 
To estimate the magnitude of the associated benefits, we would need to know how often the jury gets it right when the judge and jury disagree, what is at stake in the affected trials, and how the justice of the plea-bargaining and civil settlement processes would be affected if juries were no longer used. This information is very difficult to obtain. However, we might optimistically guess that 20 years of jury duty safeguards the rights of something on the order of one million individuals, ranging from those facing unjust seizure of property to those facing unjust incarceration and, in rare cases, even unjust execution.

Another way jury duty protects rights is by encouraging changes in unjust laws through a phenomenon known as jury nullification. In some cases (e.g., laws with implausibly harsh penalties), juries have simply refused to convict even patently guilty defendants. This has led (albeit infrequently) to legal reform that has safeguarded the rights of large numbers of individuals. $^{97}$

A second key benefit of jury duty is the economic savings associated with avoiding unjust incarceration. The average time served in prison in the United States in 2009 was 2.9 years and the average yearly cost for imprisoning a person was $\$ 31,116 .{ }^{98}$ Thus, if jury duty over 20 years prevents something on the order of 200,000 people from being unjustly imprisoned, ${ }^{99}$ the savings are on the order of $\$ 18$ billion. ${ }^{100}$

A third set of jury duty benefits relate to the civics education it provides participants. As several thinkers have argued, jury service leads jurors to enlarge their horizons beyond their

\footnotetext{
${ }^{97}$ For a history of jury nullification, see ibid., Chapter 6.

${ }^{98}$ Adam Gelb, Ryan King, and Felicity Rose, "Time Served: The High Cost, Low Return of Longer Prison Terms," (Pew Center on the States, 2012), 12-13.

${ }^{99}$ To accurately assess this number, we need to know what percentage of the roughly 600,000 jury trials where the jury and judge disagree: a) the jury gets the outcome right, b) the trials are criminal trials, and c) the jury exonerates an innocent person. We also need to know how the absence of a jury would affect the plea bargaining process. My estimate of 200,000 is admittedly highly speculative.

100 There are also the more difficult-to-quantify economic costs associated with unjust incarceration, such as prisoners' loss of skills and the economic losses associated with the discrimination they face as former prisoners.
} 
narrow self-interest to the broader common good. ${ }^{101}$ In addition, jury duty helps increase tolerance by exposing citizens to others from different walks of life. ${ }^{102}$

Finally, jury duty has important non-instrumental benefits. The greater propensity of juries to reach correct decisions increases the trial's legitimacy. ${ }^{103}$ And the fact that society asks a significant number of ordinary citizens to sit through a trial to improve the accuracy of its outcome expresses respect for those whose property, freedom, and even life may be on the line.

\subsubsection{Citizen Duty's Greater Benefits}

Even on this optimistic account of jury duty's benefits, Citizen Duty's benefits are greater still. First, Citizen Duty, even for one presidential election, arguably offers greater expected protection for rights. National policy in areas such as healthcare, social security, foreign policy, and the environment each affect the rights of tens of millions of citizens (and even hundreds of millions when we consider the effects of policies over several generations), not to mention millions of foreigners. In some cases, the relevant rights are a matter of life and death. Since the choice of president affects a large number of different policy areas, even conservative estimates of Citizen Duty's capacity to improve political outcomes implies that it provides substantially greater protection for citizens' rights compared with 20 years of jury duty.

Citizen Duty's expected economic benefits are also likely to be greater than the economic benefits of better trials. Bad policies are expensive. An unwise war, for example, not only jeopardizes lives. It also has economic costs that can run in the trillions of dollars. ${ }^{104}$ Similarly, unwisely delaying a necessary war can make the underlying problem much more difficult and

\footnotetext{
${ }^{101}$ John Stuart Mill, Considerations on Representative Government (London: Parker, Son, and Bourn, 1861 ), 68.

${ }^{102}$ For a discussion, see Singer, Jury Duty, 68-70.

${ }^{103}$ Ibid., 3-4.

${ }^{104}$ Neta Crawford, "Costs of War," (Watson Institute for International and Public Affairs, 2016).
} 
costly to address. Unwise decisions in other national policy areas have costs that can easily run in the hundreds of billions of dollars. Thus, even a conservative estimate of Citizen Duty's capacity to improve political outcomes implies that its expected economic benefits are greater than those of jury duty. Indeed, if Citizen Duty prevents one unwise war, this alone would cover the economic costs of dozens of Citizen Duty deliberations.

Citizen Duty also offers participants a better civics education than jury duty does. Note first that, while many of the citizen-days required by jury duty involve waiting in the jury pool, ${ }^{105}$ all citizen-days required by Citizen Duty involve potentially edifying deliberation. Moreover, while jury deliberations often concern narrow questions of fact about a specific incident, Citizen Duty deliberations concern policy issues and are therefore much more conducive to broadening citizens' political horizons. And since Citizen Duty explicitly aims at political diversity among participants, it has greater potential for exposing citizens to others with different views and backgrounds.

Finally, Citizen Duty's non-instrumental benefits are arguably greater than jury duty's.

First, since more is at stake for citizens' rights in a presidential election than in even 20 years of jury trials, the moral importance of ensuring that the decision is made in a respectful and legitimate way is greater. Second, while juries do not explain their decisions, Citizen Duty provides an opportunity for citizens to be given justifications for coercively-binding outcomes with which they disagree. Finally (and most importantly), the alternative to jury duty (a trial by judge) is much better than the alternative to Citizen Duty in terms of respectfulness and legitimacy. While a judge may not be as unbiased or as good in ascertaining facts as juries are, judges are highly knowledgeable and can generally be counted on to give cases careful

\footnotetext{
${ }^{105}$ Singer, Jury Duty, 62.
} 
consideration. The alternative to Citizen Duty, on the other hand, is large numbers of citizens making their electoral choice with shockingly low levels of care and minimal knowledge $-\mathrm{a}$ state of affairs that severely undermines electoral legitimacy and respectfulness.

Thus, there is a strong case for viewing the benefits of Citizen Duty for one presidential election as greater than those of even 20 years of jury duty. If the benefits of 20 years of jury duty are greater than the roughly $\$ 40$ billion and 180 million citizen-days it requires, then Citizen Duty's benefits are greater than these costs as well.

\subsection{A Liberal Justification for Citizen Duty's Coercion}

The argument above may convince liberal political philosophers that Citizen Duty's economic costs can be justified. However, liberal philosophers have long argued that coercion cannot be justified by simply appealing to large collective benefits. It instead requires careful consideration of rights and duties. ${ }^{106}$ My aim here is to argue that citizens' rights and duties justify Citizen Duty's coercion.

To make this argument, I will once again appeal to a comparison with jury duty. I will take the permissibility of jury duty's coercion as given. ${ }^{107}$ I will then propose several jury duty features that are jointly sufficient to justify its use of coercion. Finally, I will argue that Citizen Duty has these features as well.

\footnotetext{
${ }^{106}$ See, for example, Jason Brennan and Lisa Hill, Compulsory Voting: For and Against (Cambridge University Press, 2014), Section 1.9.

${ }^{107}$ Indeed, even liberals hostile to coercion (e.g., Jason Brennan) accept the permissibility of jury duty coercion. Ibid., 77.
} 


\subsubsection{The Justification for Jury Duty Coercion}

There are five features of jury duty that, taken together, plausibly justify its use of coercion. First (and most importantly), jury duty protects weighty rights. Litigants face the threat of losing their property, freedom, and, in some cases, even lives. Moreover, what is at stake for litigants is not a positive right to assistance (which some liberals discount), but rather negative rights against being subjected to unjust state power.

Second, the litigants are subject to the legal authority of the jurors' nation-state. This means that the litigants and jurors are often part of the same scheme of social cooperation, which arguably grounds a special responsibility on the part of jurors to safeguard the litigants' rights. ${ }^{108}$ It also means that the jurors are citizens of the state that is subjecting the litigants to coercive power. This also arguably gives jurors a special duty to ensure that the coercive power used in their name is exercised justly.

Third, the sacrifice jury duty demands of each coerced individual is not unreasonably high. If jury duty required 10,000 individuals to serve as jurors for life, I take it that jury duty would be impermissible. However, in the current system, most jurors only serve for a few days, receive some financial compensation for their service, enjoy legal protection from job loss, and are offered exemptions from jury service in the case of certain hardships. ${ }^{109}$

Fourth, jury duty's expected benefits are broadly distributed among those who are coerced. Any juror can potentially find herself falsely accused of wrongdoing or facing a patently unjust law and thus reliant on the protections offered by a jury of her peers. This implies that the juror and litigants often stand in relations of reciprocity, since they can each be asked to

\footnotetext{
${ }^{108}$ For one argument in favor of this factor's moral relevance, see Thomas Nagel, "The Problem of Global Justice," Philosophy \& Public Affairs 33, no. 2 (2005).

${ }^{109}$ See, for example, “Jury Frequently Asked Questions: Northern District of California," Questions, 5, 7, and 15.
} 
come to each other's aid. These relations of reciprocity arguably strengthen individuals' duties to contribute to cooperative enterprises. ${ }^{110}$ The broad distribution of jury duty's expected benefits also reduces the net expected costs that jury duty imposes on any particular individual. Indeed, for many individuals, the institution of jury duty can be seen as providing net benefits from an ex ante perspective (i.e., before one knows whether she will be a litigant or whether she will have to serve as a juror). For these individuals, jury duty can be seen, not as a coercively-imposed sacrifice for the sake of others, but rather as a coerced solution to a free-rider problem similar to the one utilized for many other types of public goods (e.g., the taxation required to pay for national defense).

Fifth, non-coercive alternatives to jury duty's coercion cannot attractively achieve similar benefits. ${ }^{111}$ If litigants' rights could be shown to be better protected by professional judges or if a purely voluntary system of jury service would work just as well as coerced jury duty, I take it that jury duty's use of coercion would be unjustified. The coercion is only warranted because there is no attractive non-coercive alternative way of delivering jury duty's key benefits (e.g., increased protection for litigants' rights).

I do not pretend that this brief discussion has established that these five features are the precise ones that justify jury duty's coercion. The justifiability of coercion is, after all, an enormously complex topic. However, my justification for Citizen Duty’s coercion does not rest on the claim that these are the precise features that justify jury duty's coercion. Rather, it rests on the claim that, whatever the features that justify jury duty's coercion are, they are also shared by Citizen Duty. Thus, though my focus will be on the five features highlighted above, the more

\footnotetext{
${ }^{110}$ For a discussion of the importance of reciprocity, see Brennan and Hill, Compulsory Voting: For and Against, 35. Brennan argues that reciprocity is not sufficient to justify coercion. However, I am only claiming here that reciprocity strengthens jurors' duty to serve and thus strengthens the case for coercion.

${ }^{111}$ For a discussion of this condition, see ibid., Section 1.11.
} 
fundamental claim that I shall defend is that jury duty and Citizen Duty are broadly similar in terms of the duties of participants and the rights they help protect.

\subsubsection{The Justification for Citizen Duty Coercion}

The similarity of Citizen Duty to jury duty in terms of the first four features highlighted above is not difficult to see. Just as individuals' rights can be threatened by an unjust trial, so, too, individuals' rights can be threatened by the unjust policies of an unwisely elected president. And just as American jurors are asked to safeguard the rights of fellow Americans, so, too, the rights that Citizen Duty aims to protect are those of the participants' compatriots. In addition, any Citizen Duty participant can potentially find herself facing an unjust proposed policy and reliant on the protections offered by fellow citizens' careful consideration of the electoral choice. Moreover, the sacrifices Citizen Duty imposes on citizens-one working day of deliberation every four years - are circumscribed.

The lack of an attractive alternative to Citizen Duty's coercion is admittedly more difficult to establish because there are so many alternatives to consider. Above, I highlighted the problems with relying exclusively non-institutionalized MED (with attempted norm change) or on institutionalized MED that relies on monetary payments as the main deliberation participation incentive. However, there are also non-coercive proposed reforms that aim at many of same benefits as Citizen Duty without relying on MED at all. I will consider these alternatives in the next section and will argue that they cannot realize anything approximating Citizen Duty's benefits, either. If so, then Citizen Duty arguably has all five features that I suggested above help justify jury duty’s coercion. 
In fact, the case for Citizen Duty's coercion is even stronger than the case for jury duty's coercion in several ways. First, as I argued above, Citizen Duty may well offer an even greater protection for rights than jury duty does. Second, the sacrifice that Citizen Duty asks of each individual is less onerous than what jury duty can sometimes demand. While particular jurors can sometimes be required to serve on juries for months, no person will be asked to deliberate for more than approximately 20 days over her lifetime. And Citizen Duty service is also more spread out and offers better remuneration compared with jury duty. Finally, the relevant coercive power that Citizen Duty aims to tame is the power of the citizens themselves (qua voters). Citizens' responsibility to ensure that this coercive power is used justly is therefore arguably even stronger than jurors'. Thus, if jury duty's coercion is justified there is a strong case for viewing Citizen Duty's coercion as justified as well.

\section{The Inadequacy of Alternatives to Mass Deliberation}

Importantly, both the consequentialist justification for Citizen Duty's costs and the liberal justification for its coercion rest on the claim that less costly reforms cannot realize Citizen Duty's benefits. Yet MED's critics have argued that there are in fact several alternative reforms that, in Arthur Lupia's words, may well “outperform [institutionalized mass electoral deliberation] or have an effect so similar that they call into question the ... bang for the bucks and return on the [time] it requires." 112 If Lupia is right, then the case for Citizen Duty collapses, and these alternative democratic reforms should be pursued instead.

\footnotetext{
${ }^{112}$ Arthur Lupia, "The Wrong Tack: Who's to Say That People Make Better Decisions in Groups Than They Do on Their Own?," Legal Affairs 3 (2004): 45.
} 
In this section, I shall consider three prominent alternatives to Citizen Duty: voter education initiatives, publicized mini-public deliberations, and improved civics education. I shall argue that none of these alternative reforms is capable of delivering anything approximating Citizen Duty's benefits.

\subsection{Voter Education Initiatives}

One alternative to institutionalized MED suggested by Lupia is a voter education initiative (e.g., encouraging citizens to visit a well-designed political website). ${ }^{113}$ Such initiatives could admittedly combat citizens' political ignorance, increase the thoughtfulness of their electoral decisions, and foster greater recognition of political disagreement-all at a fraction of Citizen Duty's costs.

However, voter education initiatives are unlikely to realize Citizen Duty's benefits for several reasons. The first is the problem of motivating citizens to engage with the educational materials. Simple encouragement is unlikely to be sufficient to induce citizens to bear the substantial time costs of becoming more informed. And, while citizens could be paid or coerced into engaging with educational materials or even barred from voting unless they become sufficiently informed, ${ }^{114}$ such solutions have a variety of obvious costs that would substantially reduce the advantages of educational initiatives over Citizen Duty.

Second, even if citizens could be induced to engage with educational materials, the learning engendered is unlikely to be as balanced as the learning that occurs at Citizen Duty. As Fishkin points out, when DP participants are tested after receiving DP briefing materials but

\footnotetext{
113 Ibid.

${ }^{114}$ For a proposal in this vein, see Jason Brennan, "The Right to a Competent Electorate," The Philosophical Quarterly 61, no. 245 (2011).
} 
before deliberating, those who engage with the briefing materials tend to learn mainly those facts and arguments that support their pre-existing views. Face-to-face deliberation seems to have a distinctive capacity for fostering balanced learning about political controversies. ${ }^{115}$

Third, educational initiatives are far less likely than Citizen Duty to increase citizens' appreciation of the political disagreement that exists among fellow citizens. Citizen Duty offers citizens an opportunity to hear the views of ordinary fellow citizens in a context in which interlocutors' facial and body language can provide distinctive evidence of sincerity. ${ }^{116} \mathrm{By}$ contrast, the opposing views presented in educational materials can all too easily be dismissed as those of out-of-touch elites, experts corrupted by special interests, or committed ideologues.

Finally, education initiatives cannot realize the many other benefits unique to deliberation. Such initiatives do not physically bring together citizens from different walks of life and thus do not have the same potential for increasing tolerance. They also do not provide citizens with an opportunity to be heard by fellow citizens. And, while educational initiatives can provide citizens with justifications for unwelcome electoral outcomes, they cannot provide citizens with assurances that these justifications (as opposed to various forms of prejudice or ignorance) are in fact motivating voters on the opposing side. Thus, educational initiatives are unlikely to realize anything approximating Citizen Duty's benefits.

\subsection{Publicized Mini-Public Deliberations}

A second alternative to MED advocated by John Gastil (among others) is publicizing the deliberations of small, representative groups of citizens (mini-publics). ${ }^{117}$ This idea has the

\footnotetext{
115 Ackerman and Fishkin, Deliberation Day, 53.

${ }^{116}$ For a discussion, see Marcus Holmes, "The Force of Face-to-Face Diplomacy: Mirror Neurons and the Problem of Intentions," International Organization 67, no. 04 (2013).

117 Gastil, By Popular Demand.
} 
potential to avoid some of the problems with other types of education initiatives. Citizens who follow the mini-publics' deliberations (e.g., by watching clips of key arguments online) would learn about the views of ordinary fellow citizens. And even those who do not follow the minipublics' deliberations may nevertheless be substantially swayed by the mini-publics' conclusions in their voting behavior. ${ }^{118}$ If so, then this proposal could achieve many of Citizen Duty's benefits without coercion and without the massive expense of engaging tens of millions of citizens in deliberation.

However, this proposal also has several shortcomings. First, as in the case of other voter education initiatives, it is unclear how citizens can be motivated to pay attention to the minipublics' proceedings. Indeed, following the unpolished, often meandering deliberation of ordinary citizens is likely to be even less appealing to many citizens than engaging with a welldesigned political website.

Gastil's more modest hope that mere knowledge of the mini-publics' conclusions could reliably influence voting behavior also seems overly optimistic. First, it is unclear why citizens looking for voting cues should look to the mini-publics' conclusions. Why not look instead to opinion leaders from their own group? After all, these opinion leaders are likely to better represent citizens' values and interests than the majority of a representative group of fellow citizens. Second, citizens may not necessarily trust the mini-publics. Such trust requires confidence in the integrity of the mini-public's design. It also requires a basic understanding of the mini-public's recommendation (to evaluate whether it is reasonable). Yet, just as it is difficult to motivate citizens to pay attention to the mini-public's proceedings, so, too, it is doubtful that

${ }^{118}$ Ibid., 171-179. 
citizens will voluntarily gather sufficient information about the mini-public to trust its conclusions.

Indeed, evidence from real-world experiments with mini-publics supports many of these doubts. In one set of such experiments, several Canadian provinces asked mini-publics to determine which alternative to the existing first-past-the-post voting system (if any) should be adopted. The mini-publics' recommendations were then publicized and put to a referendum. ${ }^{119}$ The results of this experiment are not encouraging for mini-publics' proponents. First, despite fairly substantial media coverage, about a week before the vote in British Columbia (BC), $66 \%$ of citizens polled admitted to knowing "little or nothing" about the proposed single transferable voting system endorsed by the mini-public. ${ }^{120}$ In Ontario, $81 \%$ admitted to knowing little or nothing about the Mixed Member Proportional system endorsed by that province's minipublic. ${ }^{121}$ The vast majority of voters did not even take the time to become minimally informed about the basics of the voting system that the mini-publics endorsed, let alone the details of the mini-public's deliberation.

The Canadian experience also casts doubt on the claim that citizens can be reliably swayed by mini-publics' recommendations. Admittedly, over 57\% of voters in BC voted for the single transferable vote proposal endorsed by the BC mini-public (just short of the threshold required to pass the reform). ${ }^{122}$ However, proposals for voting reform in Ontario, Prince Edward's Island, and the second attempt at voting reform in BC—all endorsed by mini-publicswere all rejected by more than 60 percent of the electorate. ${ }^{123}$ Thus, conducting and publicizing

\footnotetext{
${ }^{119}$ For a brief overview of mini-publics' role in Canada's attempted electoral reforms, see Lawrence Leduc, "The Failure of Electoral Reform Proposals in Canada," Political Science 61, no. 2 (2009).

${ }^{120}$ See Ipsos-Reid, "Two-Thirds Still Know Very Little or Nothing About Bc-Stv," accessed June 5, 2019, http://www.ipsos-na.com/news-polls/pressrelease.aspx?id=2665.

${ }^{121}$ Leduc, "The Failure of Electoral Reform Proposals in Canada," 30-31.

122 See ibid., 25.

${ }^{123}$ Ibid.
} 
mini-public deliberations does not seem to provide a compelling substitute for including citizens as active participants in the right kind of mass deliberation.

\subsection{Reforming Civics Education}

The final alternative to Citizen Duty that I shall consider here is reforming civics education. As Hibbing and Theiss-Morse argue, reformed civics education could increase students' political knowledge and give them the skills and desire to deliberate and remain informed throughout their lives. Civics education could also be used to emphasize the existence of political disagreement among fellow citizens. ${ }^{124}$ And while civics education reform is certainly not costless, its economic costs are far lower than Citizen Duty's.

However, reforming civics education cannot realize Citizen Duty's benefits, either. First, the task of achieving the benefits of MED via civics education faces many of the same difficulties facing adult education initiatives. Simply presenting alternative political views to students may lead them to focus only on arguments consistent with their pre-existing views or may leave them skeptical regarding whether fellow citizens really hold the views presented by their teacher. Relying on classroom deliberation would avoid these problems. But such deliberation would exclude the views of older citizens and those from different communities. ${ }^{125}$

Second, the capacity of civics education to engender widespread, constructive political discussions across political lines among adults is doubtful. Many of the problems are similar to those I highlighted when considering Mutz's proposal for norm change. Addressing political intolerance and the acceptability of political ignorance via civics education is difficult. And other

\footnotetext{
${ }^{124}$ Hibbing and Theiss-Morse, Stealth Democracy, 225-226.

125 Solutions to these problems are possible, but they would be expensive.
} 
important obstacles (e.g., local political homogeneity) cannot be addressed by civics education, at least not in any substantial way.

Yet without large increases in constructive deliberation across political lines among nonstudents, deliberation among students would have only circumscribed benefits. Deliberation limited largely to students would not provide citizens with an opportunity to learn about contemporary political issues nor with an opportunity to be heard by other citizens regarding the issues at stake in current elections. Indeed, even the appreciation of political disagreement engendered by student deliberation may not be long-lasting. Citizens might affirm that there was substantial disagreement regarding the suitability of candidate A vs. B or regarding how issue C should be resolved among ordinary citizens when they were students 20 years ago. But without engaging in constructive deliberation across political lines again, they may well come to believe that no reasonable person could support candidate $\mathrm{X}$ over $\mathrm{Y}$ or policy $\mathrm{Z}$ today.

Finally, even if civics education is entirely successful, its benefits will take many years to materialize. Those who undergo this education will not constitute even a bare majority of American voters for around a quarter of a century. Yet the problems that Citizen Duty aims to address are pressing. Thus, civics education reform also does not offer a compelling substitute for Citizen Duty.

In sum, it is tempting to think that Citizen Duty's benefits can be realized through less costly or radical reforms. However, the alternatives proposed by MED's opponents cannot increase citizens' political knowledge, improve appreciation of political disagreement, foster civic virtue, and increase the legitimacy and respectfulness of elections in the same way as asking a majority of citizens to engage in carefully designed, moderated deliberation across 
political lines prior to major elections. Thus, while these alternatives (e.g., civics education reform) may well be worth pursuing alongside Citizen Duty, they are no substitute for it.

\section{The Political Feasibility Objection}

Even if all of the arguments advanced thus far are compelling, some readers may nevertheless dismiss Citizen Duty as politically quixotic. As Simone Chambers writes in response to Deliberation Day, “Although I applaud the 'utopian realism' of Ackerman and Fishkin's Deliberation Day ..., I do not suppose that this will happen in the near future."126

Although Chambers does not give reasons for her skepticism, the obstacles to implementing a reform like Deliberation Day or Citizen Duty are not difficult to see. First, political elites may be seen as unlikely to support such a radical, costly, and potentially destabilizing political reform. Second, citizens may be seen as unlikely to support an expensive political reform that requires them to engage in an activity that many of them find distasteful. ${ }^{127}$ If Citizen Duty is utopian, then both practically-minded political philosophers and democratic reformers would be well-advised to turn their attention elsewhere.

However, Citizen Duty is substantially less utopian than it initially appears. First, political elites may now be more open to proposals that threaten the political status quo than they were in the past. A variety of political outcomes, from the election of Jeremy Corbyn to head the Labour Party in the UK to the election of Donald Trump in the United States were strongly opposed by many political elites. ${ }^{128}$ There are, to be sure, legitimate reasons to support both

\footnotetext{
${ }^{126}$ Simone Chambers, "Behind Closed Doors: Publicity, Secrecy, and the Quality of Deliberation," Journal of Political Philosophy 12, no. 4 (2004): fn. 57.

${ }^{127}$ See Neblo et al., "Who Wants to Deliberate—and Why?," 567.

${ }^{128}$ On the Labour Party establishment's opposition to Jeremy Corbyn, see Zack Beauchamp, "Jeremy Corbyn, the Socialist Who's Tearing Britain's Labour Party Apart, Explained," Vox, accessed June 5, 2019, https://www.vox.com/2015/8/13/9149623/jeremy-corbyn. On the Republican Party establishment's opposition to
} 
Corbyn and Trump. However, the problems that Citizen Duty aims at addressing (e.g., a

perception of establishment politicians as corrupt and a disdain for political compromise) are part of the reason for these candidates' success — or so many political elites believe. Elites who fear the success of similar anti-establishment candidates or movements may now be more open to supporting democratic reforms aimed at addressing the political pathologies that are increasingly threatening the established democratic order. France's Grand Debate, a national deliberative consultation implemented by President Macron (partly as a way of defusing the Yellow Vest Movement), is an example of such openness to novel deliberative reforms. ${ }^{129}$

Second, citizens' distaste for participating in Citizen Duty may not be as strong as it first appears. Though many citizens admittedly do not particularly want to deliberate about politics, as with other aspects of deliberation, institutional design matters. As Michael Neblo and his coauthors argue, there is in fact a fairly high willingness among citizens to deliberate about politics in certain contexts. ${ }^{130}$ Citizen Duty would be well-organized and moderated. It would have a fairly predictable agenda and would ensure deliberators are compensated for their time. It would give citizens information about key relevant topics ahead of time. And its non-local character would alleviate fears of social sanctions. Many of these factors have been shown to significantly reduce citizens' distaste for deliberating. ${ }^{131}$

\footnotetext{
Donald Trump, see John Gibson, "Establishment Republicans Reject Trump. Problem: Where Will They Get Voters?," Fox News, accessed June 5, 2019, http://radio.foxnews.com/2016/10/18/establishment-republicans-rejecttrump-problem-where-will-they-get-voters/.

${ }^{129}$ For description, see Hugh Schofield, "Gilets Jaunes: Will Macron's Grand Debate Tackle French Crisis?," BBC News, accessed June 5, 2019, https://www.bbc.com/news/world-europe-46878317.

${ }^{130}$ See Neblo et al., "Who Wants to Deliberate_-and Why?," 573.

${ }^{131}$ Hibbing and Theiss-Morse (Stealth Democracy, 110) find that the factor that most dampens support for greater citizen involvement in politics is citizen ignorance. A form of deliberation that gave citizens sufficient information ahead of time might be viewed as less intimidating. Neblo and his coauthors ("Who Wants to Deliberate- and Why?," 574) found that even a modest payment "as thanks" for participation increased willingness to participate substantially.
} 
Third, even if most citizens find the prospect of participating in Citizen Duty unappealing, this does not imply that they would reject Citizen Duty as an institution. To take an analogy, if we only looked only at citizens' willingness to participate in jury duty, we would drastically underestimate its public support. While most citizens are hardly eager to serve as jurors, ${ }^{132}$ they (by and large) support jury duty as an institution due to its perceived social benefits. ${ }^{133}$ Similarly, support for Citizen Duty depends, not only on citizens' distaste for participating in political deliberation, but also on citizens' perceptions of Citizen Duty's broader benefits.

These perceived benefits are likely to be substantial. As Hibbing and Theiss-Morse point out, many citizens recognize that part of the problem with politics is that ordinary people are failing in their civic duty to become politically informed. ${ }^{134}$ Citizens might therefore be willing to support an institution that provides them with an opportunity to discharge this civic duty, at least as long as what is asked of them is circumscribed and as long as fellow citizens are simultaneously required to do their part as well. Moreover, many citizens are aware of some of the problems that Citizen Duty aims to address, such as the increasingly divisive and intolerant nature of contemporary politics. ${ }^{135}$ They may therefore be willing to support an institution aimed at addressing these problems.

Finally, citizens who mistakenly believe in political consensus may actually overestimate Citizen Duty's benefits. They might see Citizen Duty as a way of mobilizing the electorate to

\footnotetext{
132 S.C. Losh, A.W. Wasserman, and M.A. Wasserman, "Reluctant Jurors: What Summons Responses Reveal About Jury Duty Attitudes," Judicature 83 (1999).

133 Singer, Jury Duty, 32.

${ }^{134}$ Hibbing and Theiss-Morse, Stealth Democracy, 116.

135 John Wagner and Scott Clement, "'It's Just Messed Up': Most Think Political Divisions as Bad as Vietnam Era, New Poll Shows," The Washington Post, accessed June 5, 2019, https://www.washingtonpost.com/graphics/2017/national/democracy-poll/?hpid=hp_hp-more-top-stories_pollsaturday\%3Ahomepage\%2Fstory\&utm_term=.a00ec56b632a.
} 
pressure the dysfunctional and corrupt representative institutions to implement commonlyagreed-upon solutions to commonly-agreed-upon problems. Of course, in most cases, these citizens' hopes will prove false given the political disagreement that actually exists in the electorate. However, citizens' pathological underappreciation of political disagreement could ironically engender support for a reform like Citizen Duty aimed at addressing this very pathology. For all these reasons, Citizen Duty is not as politically utopian as it might first appear.

\section{Conclusion}

Several democratic theorists have called for greater mass electoral deliberationdeliberation by a large proportion of citizens regarding the issues at stake in elections. However, such calls face skepticism about deliberation's purported benefits, concerns about its dangers and costs, and doubts about its political feasibility.

In response, I have argued that there is a form of mass electoral deliberation - Citizen Duty - that offers compelling replies to these objections. Citizen Duty takes seriously the challenges of achieving broad participation in constructive deliberation via careful design of the deliberative environment, legally-required attendance, trained moderators, and substantial travel requirements. I have argued that these measures would enable Citizen Duty to scale up the wellstudied success of Deliberative Polls, thus realizing the promise of mass electoral deliberation.

Some might dismiss Citizen Duty as too costly. But if society is willing to pay billions of dollars and employ coercion for the benefits generated by jury duty, the substantially greater benefits of Citizen Duty can justify these costs as well. Others might dismiss Citizen Duty as utopian. However, a careful examination citizens' attitudes towards deliberation and politics suggest that this proposed reform is not as quixotic as it might first appear. 
Many questions remain for future research. What effects would Citizen Duty deliberation have on participants? How would Citizen Duty affect (and be affected by) the various elements of the broader electoral system? Should Citizen Duty be used in other democratic contexts besides presidential elections in the United States (e.g., referenda)? If so, how? My aim in this article has been to motivate inquiry into such questions by arguing that Citizen Duty is an idea with enormous potential—one that deserves to be taken seriously by those concerned with addressing the very serious problems facing contemporary democracies.

London School of Economics and Political Science

j.m.mazor@1se.ac.uk

\section{References}

Ackerman, Bruce, and James Fishkin. Deliberation Day. New Haven, CT: Yale University Press, 2004.

Beauchamp, Zack. "Jeremy Corbyn, the Socialist Who's Tearing Britain's Labour Party Apart, Explained." Vox, https://www.vox.com/2015/8/13/9149623/jeremy-corbyn.

Beck, Katie. "Australia Election: Why Is Voting Compulsory?" BBC News, http://www.bbc.com/news/world-asia-23810381.

Bicchieri, Cristina. Norms in the Wild: How to Diagnose, Measure, and Change Social Norms. Oxford: Oxford University Press, 2016.

Bishop, Bill. The Big Sort: Why the Clustering of Like-Minded America Is Tearing Us Apart. New York, NY: First Mariner Books, 2008.

Brennan, Jason. "The Right to a Competent Electorate." The Philosophical Quarterly 61, no. 245 (2011): 700-724.

Brennan, Jason, and Lisa Hill. Compulsory Voting: For and Against. Cambridge University Press, 2014.

Chambers, Simone. "Behind Closed Doors: Publicity, Secrecy, and the Quality of Deliberation." Journal of Political Philosophy 12, no. 4 (2004): 389-410.

Crawford, Neta. "Costs of War." Watson Institute for International and Public Affairs, 2016.

Elfin, Margery, and Carolyn Kawecki. "A Tale of Two Incumbencies." PS: Political Science \& Politics 26, no. 03 (1993): 511-515.

Farrar, Cynthia, James Fishkin, Donald Green, Christian List, Robert Luskin, and Elizabeth Paluck. "Disaggregating Deliberation's Effects: An Experiment within a Deliberative Poll." British Journal of Political Science 40, no. 2 (2010): 333-347.

Fishkin, James. The Voice of the People. New Haven, CT: Yale University Press, 1995. 
- When the People Speak: Deliberative Democracy and Public Consultation. Oxford: Oxford University Press, 2009.

Fishkin, James, Alice Siu, Robert Luskin, Nuri Kim, Andreas Katsanevas, and Yushu Zhou. "What's Next California Report: Summary Results." Stanford University: Center for Deliberative Democracy, 2011.

Frey, Bruno, and Reto Jegen. "Motivation Crowding Theory." Journal of Economic Surveys 15, no. 5 (2001): 589-611.

Frohlich, Thomas, and Alexander Kent. "The Most Democratic County in Every State." Huffington Post, http://247wallst.com/special-report/2016/10/08/the-most-democraticcounty-in-every-state/2/?utm_source=huffingtonpost.com\&utm_medium=referral\&utm _campaign=pubexchange_article.

Gastil, John. By Popular Demand. Berkeley, CA: University of California Press, 2000.

Gelb, Adam, Ryan King, and Felicity Rose. "Time Served: The High Cost, Low Return of Longer Prison Terms." Pew Center on the States, 2012.

Gibson, James, Gregory Caldeira, and Lester Spence. "Why Do People Accept Public Policies They Oppose? Testing Legitimacy Theory with a Survey-Based Experiment." Political Research Quarterly 58, no. 2 (2005): 187-201.

Gibson, John. "Establishment Republicans Reject Trump. Problem: Where Will They Get Voters?" Fox News, http://radio.foxnews.com/2016/10/18/establishment-republicansreject-trump-problem-where-will-they-get-voters/.

Gutmann, Amy, and Dennis Thompson. Democracy and Disagreement. Cambridge, MA: Belknap Press, 1996.

—. "The Mindsets of Political Compromise." Perspectives on Politics 8, no. 04 (2010): 1125-1143.

- Why Deliberative Democracy? Princeton, NJ: Princeton University Press, 2004.

Hastie, Reid, David Schkade, and Cass Sunstein. "What Happened on Deliberation Day?". California Law Review 95 (2007): 915-945.

Hibbing, John, and Elizabeth Theiss-Morse. Stealth Democracy. Cambridge: Cambridge University Press, 2002.

Holmes, Marcus. "The Force of Face-to-Face Diplomacy: Mirror Neurons and the Problem of Intentions." International Organization 67, no. 04 (2013): 829-861.

Ipsos-Reid. "Two-Thirds Still Know Very Little or Nothing About Bc-Stv." http://www.ipsosna.com/news-polls/pressrelease. aspx?id=2665.

Iyengar, Shanto, and Sean Westwood. "Fear and Loathing across Party Lines: New Evidence on Group Polarization." American Journal of Political Science 59, no. 3 (2015): 690-707.

"Jury Frequently Asked Questions: Northern District of California." http://www.cand.uscourts.gov/juryfaq.

Kaplanoglou, Georgia, and Vassilis T Rapanos. "Why Do People Evade Taxes? New Experimental Evidence from Greece." Journal of Behavioral and Experimental Economics 56 (2015): 21-32.

Kelman, Steven. "Cost-Benefit Analysis: An Ethical Critique." AEI Journal on Government and Society Regulation, January/February (1981): 33-40.

Larmore, Charles. "The Moral Basis of Political Liberalism." Journal of Philosophy 96, no. 12 (1999): 599-625.

Leduc, Lawrence. "The Failure of Electoral Reform Proposals in Canada." Political Science 61, no. 2 (2009): 21-40. 
Losh, S.C., A.W. Wasserman, and M.A. Wasserman. "Reluctant Jurors: What Summons

Responses Reveal About Jury Duty Attitudes." Judicature 83 (1999): 304.

Lupia, Arthur. "The Wrong Tack: Who's to Say That People Make Better Decisions in Groups Than They Do on Their Own?". Legal Affairs 3 (2004): 43-45.

Mansbridge, Jane. Beyond Adversary Democracy. New York: Basic Books, 1980.

Mill, John Stuart. Considerations on Representative Government. London: Parker, Son, and Bourn, 1861.

Mutz, Diana. Hearing the Other Side. New York: Cambridge University Press, 2006.

Nagel, Thomas. "The Problem of Global Justice." Philosophy \& Public Affairs 33, no. 2 (2005): 113-147.

Neblo, Michael, Kevin Esterling, Ryan Kennedy, David Lazer, and Anand Sokhey. "Who Wants to Deliberate - and Why?". American Political Science Review 104, no. 03 (2010): 566583.

Newman, Mark. "Maps of the 2016 United States Presidential Election Results." http://wwwpersonal.umich.edu/ mejn/election/2016/.

Popkin, Samuel. The Reasoning Voter. Chicago: University of Chicago Press, 1991.

Sabl, Andrew. "Deliberation in Its Place." Election Law Journal 4, no. 2 (2005): 147-152.

Sanders, Lynn. "Against Deliberation." Political Theory 25, no. 3 (1997): 347-376.

Schofield, Hugh. "Gilets Jaunes: Will Macron's Grand Debate Tackle French Crisis?" BBC News, https://www.bbc.com/news/world-europe-46878317.

Shapiro, Ian. "The State of Democratic Theory: A Reply to James Fishkin." Critical Review of International Social and Political Philosophy 8, no. 1 (2005): 79-83.

Singer, Michael. Jury Duty: Reclaiming Your Political Power and Taking Responsibility. Santa Barbara, CA: ABC-CLIO, 2012.

Skandera, Hanna, and Richard Sousa. School Figures: The Data Behind the Debate. Stanford, CA: Hoover Press, 2003.

Sunstein, Cass. Why Societies Need Dissent. Cambridge, MA: Harvard University Press, 2003.

Thompson, Dennis. "Deliberative Democratic Theory and Empirical Political Science." Annual Review of Political Science, no. 11 (2008): 497-520.

. "The Role of Theorists and Citizens in Just Elections: A Response to Professors Cain, Garrett, and Sabl." Election Law Journal 4, no. 2 (2005): 153-162.

Wagner, John, and Scott Clement. "'It's Just Messed Up': Most Think Political Divisions as Bad as Vietnam Era, New Poll Shows." The Washington Post, https://www.washingtonpost.com/graphics/2017/national/democracy-poll/?hpid=hp_hpmore-top-stories_poll-saturday\%3Ahomepage\%2Fstory\&utm_term=.a00ec56b632a.

"What's Next California: Event Agenda." http://action.nextca.org/page//WhatsNextCA_EventAgenda.pdf. 